\title{
The Consolidation of the ESG Rating Industry as an Enactment of Institutional Retrogression
}

Avetisyan, Emma; Hockerts, Kai

Document Version

Accepted author manuscript

Published in:

Business Strategy and the Environment

DOI:

10.1002/bse.1919

Publication date:

2017

License

Unspecified

Citation for published version (APA):

Avetisyan, E., \& Hockerts, K. (2017). The Consolidation of the ESG Rating Industry as an Enactment of Institutional Retrogression. Business Strategy and the Environment, 26(3), 316-330.

https://doi.org/10.1002/bse.1919

Link to publication in CBS Research Portal

\section{General rights}

Copyright and moral rights for the publications made accessible in the public portal are retained by the authors and/or other copyright owners and it is a condition of accessing publications that users recognise and abide by the legal requirements associated with these rights.

\section{Take down policy}

If you believe that this document breaches copyright please contact us (research.lib@cbs.dk) providing details, and we will remove access to the work immediately and investigate your claim.

Download date: 26. Apr. 2023
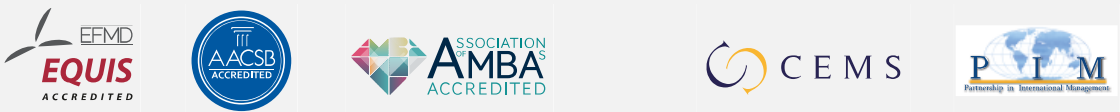


\section{The Consolidation of the ESG Rating Industry as an Enactment of Institutional Retrogression Emma Avetisyan and Kai Hockerts}

Journal article (Accepted manuscript*

\section{Please cite this article as:}

Avetisyan, E., \& Hockerts, K. (2017). The Consolidation of the ESG Rating Industry as an Enactment of Institutional Retrogression. Business Strategy and the Environment, 26(13), 316-330. 001: 10.1002/bse.1919

This is the peer reviewed version of the article, which has been published in final form at

๑Ol: https://doi.org/10.1002/bse.1919

This article may be used for non-commercial purposes in accordance with

Wiley Terms and Conditions for Self-Archiving

* This version of the article has been accepted for publication and undergone full peer review but has not been through the copyediting, typesetting, pagination and proofreading process, which may lead to differences between this version and the publisher's final version AKA Version of Record. 


\title{
CONSOLIDATION OF THE ESG RATING INDUSTRY AS ENACTMENT OF INSTITUTIONAL RETROGRESSION
}

\author{
Emma Avetisyan* \\ Audencia Business School \\ 8 Route de la Jonelière \\ 44312 Nantes Cedex 3 \\ France \\ E-mail: eavetisyan@audencia.com \\ Tel : 0033 (0)240378119
}

\author{
Kai Hockerts \\ Centre for Corporate Social Responsibility (cbsCSR) \\ Copenhagen Business School \\ Porcelænshaven 18 \\ DK-2000 Frederiksberg \\ Danemark \\ E-mail: Kho.msc@cbs.dk
}

*Corresponding author 


\title{
CONSOLIDATION OF THE ESG RATING INDUSTRY AS ENACTMENT OF INSTITUTIONAL RETROGRESSION
}

\begin{abstract}
Since the late 1980s, a plethora of Environmental, Social and Governance (ESG) rating agencies have sprung up, developing new rating methodologies to meet the (new) needs of concerned investors and to help companies to improve their CSR performance. Since 2005, the industry of ESG ratings has witnessed an important number of both national and crossborder consolidations. Based on a set of 37 interviews and secondary data, the paper reveals growth strategies of ESG rating agencies and explores the driving forces and impacts behind this wave of consolidation. Our focus is on four ESG rating agencies based in the United States, the United Kingdom, France and Switzerland. We have found financial motivation to be the main driver of consolidation. Additionally, and according to the perceptions of the ESG experts interviewed, a decrease in employee motivation coupled with a decrease in the quality of ESG research was observed to be one of the negative impacts of consolidation.
\end{abstract}

Keywords: ESG rating agencies, growth strategies, industry consolidation, socially responsible investing. 


\section{INTRODUCTION}

Over the past two decades, with the global spread of the Socially Responsible Investment (SRI) movement, the importance of Environmental, Social and Governance (ESG) rating agencies has become more pronounced among investors who are interested in screening companies based on non-financial criteria. The emergence and further evolution of these rating agencies as new institutions resulted from the convergence of interest of various stakeholders of the Corporate Social Responsibility (CSR) field (Avetisyan and Ferrary, 2013) such as investors, companies and regulators.

ESG rating agencies provide investor-solicited and company-solicited rating services, corporate research, compliance and consulting services analogous to those provided by a credit rating agencies - but with a focus on ESG criteria.

While the research publications addressing credit rating industry encompass rich investigative work emanating from scholars (with various disciplinary approaches), journalists, freelance authors, self-reflecting practitioners and consultants, the research on ESG rating industry is relatively less diverse and developed, despite several publications in Academy of Management Journal (Graves and Waddock, 1994; Thomas and Simerly, 1995; Turban and Greening, 1996; Berman et al., 1999; Johnson and Greening 1999), Strategic Management Journal (Waddock and Graves, 1997b), Journal of Management (Ruf et al.,1998) Although these publications were an important step in legitimizing ESG data in the academic community as indicators for the measurement of Corporate Social Performance (CSP), ESG rating agencies still lack the merit being the focus of sustained research topic in management scholarship as compared to consulting firms. Given their visible influence on the behaviour of investors and companies (Slager et al., 2012).

and have paid even less attention to the origins, historical evolution and growth strategies of ESG rating agencies and industry structure in general, which is much needed to improve our understanding of the development of this industry and of how different growth strategies explain current consolidation trend and its impacts.

This paper attempts to give the first overview of growth strategies of ESG rating agencies and therefore explores the driving forces and impacts of current consolidation trend.

In the remainder of the paper, we first do a literature review on ESG rating agencies. In this part we also present growth strategies and consolidation of a parallel industry of accounting and management consulting firms. We then outline the methods of our study, which comprise 
cases selection, research methodology, data collection and analyses processes. In the section that follows, we give a brief description of our cases and present their revenue models, which partly explain their choice of growth strategy. Later, we present and relate our findings to our research questions and compare them with accounting and management consulting industry. We conclude with final comment on positive and negative impacts of consolidation and give avenues for future research.

\section{LITERATURE REVIEW}

\section{ESG rating agencies}

The last two decades have seen a growing interest in socially responsible investing (SRI) by individual and institutional investors (Hutton and d'Antonio, 1998; Schueth, 2003; Johnsen, 2003; Vallentin, 2003; Sparkes and Cowton, 2004; Hill et al., 2007; Fieseler, 2011). This trend has had two main consequences. On the one hand, firms have become much more sophisticated in their communications regarding ESG topics (Hockerts and Moir, 2004; Morsing and Schultz, 2006; Vandekerckhove et al., 2008). On the other hand, we have seen the emergence and evolution of specialized ESG rating agencies (Koellner and Weber, 2005; 2008; Collison et al., 2009; Scalet and Kelly, 2010; Delmas and Blass, 2010).

We use the term ESG rating agencies as an umbrella term intended to cover a number of similar terms. Often, ESG rating agencies are also referred to as CSR) rating agencies (Avetisyan and Ferrary, 2013; Scalet and Kelly, 2010) or social rating agencies (Arjaliès, 2010; Chatterji and Toffel, 2010; Chatterji et al., 2009; Igalens and Gond, 2005). We realize that there are subtle differences between the ways in which these terms are used. We will look at the different philosophies of those organizations in the 'data description' section. However, for the majority of the paper, we will use ESG rating agencies as our umbrella terminology. In the research community, especially KLD Research \& Analytics Inc. (hereafter referred to as KLD) data, has been widely used in academic studies of CSR and SRI (Graves and Waddock, 1994; Brown and Perry, 1994; Berman et al., 1999; Waddock and Graves, 1997, Ruf et al., 1998). According to Harrison and Freeman (1999), KLD Social Ratings data is the most frequently cited source of CSP in academic researches, and it has been quoted as being 'the de facto research standard for measuring CSP' in academic research (Waddock, 2003). Chatterji et al. (2009) suggest that KLD's social and environmental ratings are among the oldest and most influential and, by far, the most widely analyzed by academics. 
Meanwhile, skeptics argue that ESG ratings cannot truly discern which firms are socially responsible, and that such ratings result in metrics that are often invalid and can be misleading to stakeholders (Entine, 2003a). As such, Vogel's 2005 study, which compared returns of the KLD Domini 400 Social Index and the S\&P 500 (between May 1990 and June 30" 2004), revealed that KLD outperformed $\mathrm{S} \& \mathrm{P}$, but this difference is largely attributable to the industries in which the fund invested; there was no evidence of a social factor. Moreover, according to Galbreath (2013), the governance dimension of the KLD database appears to lack a robust assessment of dimensions considered critical in the literature. Finally, raters are accused of 1) giving high marks to firms that are later more likely to be embroiled in scandals, and 2) relying upon often unreliable, anecdotal, and highly interpretable data (Entine, 2003a, 2003b).

However, whether their measurements are accurate or not, ESG rating agencies undoubtedly influence the behavior of firms and investors. Addressing ESG issues has become a point of interest as a risk-management concern for investors, shareholders and governments; for firms, addressing these issues has become an emerging part of competitive strategy (Galbreath, 2013). If in the early 1990s, the majority of companies were not interested in CSR and SRI conversations, over time they started to value their ratings and communicate about the subject both internally and externally (Slager et al., 2012). The investment community in particular sees ESG as important, because ESG issues are increasingly seen as being financially 'material' to an investment portfolio (Richardson, 2009), and ESG criteria is considered to be a crucial value for success (Hart and Milstein, 2003, p. 57) while investors are looking for greater transparency in relation to a firm's performance (Harrison and Freeman, 1999).

From theoretical perspective, recent studies used ESG data to advance the theorization of the institutional dynamics of CSR standardization, shedding a new light on this dynamics, the tensions that structure each level of analysis, and the interrelationships between standardization processes across levels of analysis. Other studies explored the role of CSR rating agencies in the institutionalization of the CSR field and investigate historical construction of certain CSR rating agencies by mobilizing prior sociological and historical works on calculative practice, commensuration and measurement (Gond and Avetisyan, 2014, Avetisyan and Ferrary, 2013).

We now turn to present growth strategies and consolidation of accounting and management consulting firms. 


\section{Growth strategies and consolidation of accounting and management consulting firms}

Mergers and acquisitions have become an increasingly common way of growth for auditing and management consulting firms since 1980s. During this period, management-consulting firms grew faster than the economy as a whole in many Western nations (Kipping and Clark, 2012) and the field became even more attractive for accounting firms, which were already providing 'management advisory services' to their clients.

Meanwhile, in the first phases of their development accounting firms adopted an external growth strategy through partnerships or by forming alliances with local firms, except Arthur Andersen, which expanded organically by opening its own offices internationally. Around 1980s Arthur Andersen (renamed Guy Barbier at that time) acquired GPA (Peyronet Gauthier) in order to obtain a number of large French clients. Arthur Andersen, from its formation had seen itself more as a provider of business advice than as a mere accounting firm, which differentiated it from other accounting firms and contributed to its rapid growth (McDougald and Greenwood, 2012). The fact that five of the top ten management-consulting firms in the nation were accounting firms raised the potential conflict of interests as auditing firms were providing consulting services to the same clients. In the 1980 s, all the auditing firms of Big 8 used acquisitions to face strong competitive pressures but also to push further their growth strategies (e.g. Price Waterhouse merging with BEFEC in 1989 and Deloitte merging with Calan Ramolino in 1997). To accelerate growth of its consulting activities and access new client segments in the United Kingdom, Price Waterhouse acquired Urwick Orr and Partners in 1985 (Jones 1995, pp. 314-315). Auditing firms entering new markets had to grow quickly to reach a size at which their operations would be cost-competitive with incumbent firms if they are to survive (Garnsey, 1998; Porter, 1980; Shane, 1996).

In 1987, the Big 8 transformed into Big 6 when Ernst \& Whinney merged with Arthur Young to form Ernst and Young, and Deloitte, Haskins \& Sells merged with Touche Ross to form Deloitte \& Touche. More than a decade later, in 1998 the Big 6 became the Big 5 when Price Waterhouse merged with Coopers \& Lybrand to form PricewaterhouseCoopers. Downplaying their roots in accounting and portraying themselves as a different type of advisory firm, the Big 5 began rebelling themselves as 'business advisory firms', 'multidisciplinary practices' or 'professional service firms' (Hining et al., 1999). Finally, the Big 5 became the Big 4 after the demise of Arthur Andersen in 2002 as a consequence of 


\section{Enron Scandal.}

Kipping and Clark (2012) summarized three main possible arguments in the academic literature to explain the wave of mergers in this industry: 1) large size, which enable firms to spread the costs involved in the development and deployment of new technologies, 2) the growing sophistication of clients, especially the growing number of international and transnational clients, 3 ) firms' difficulties to position themselves as number one.

Regarding the literature on consolidation of accounting and management consulting firms, a recent study by Francis et al. (2013) revealed concerns raised by high-profile reports in the United States, the United Kingdom, and the European Union over the concentration of supply by the Big Four accounting firms, and the potentially adverse effect this concentration may have on audit markets and the quality of audits in these legal jurisdictions (European Commission, 2010; General Accounting Office 2003; Government Accountability Office, 2008; House of Lords, 2010; Oxera, 2006, 2007; United States Treasury, 2006, 2008).

The report from the General Accounting Office (GAO, 2003) states that audit quality is considered to have fallen by some measures in the past years, although not as a result of fewer audit firms. Linking audit quality to consolidation has been difficult, and the results have been inconclusive. The report of Government Accountability Office (2008) continued to warn of potentially negative effects resulting from market concentration. Meanwhile, Henry Paulson, the Secretary of the U.S. Treasury (2006-2009), mentioned that "The Big Four firms dominate the industry in terms of revenues and professional staff; the remaining accounting firms face significant barriers to competing with the Big Four, at a time when auditors are in real demand."

This situation raised several questions about the credit-rating industry's sustainability and effectiveness, given the importance of accounting to the U.S. financial system (United States Treasury, 2006), and it led to the formation of an ad hoc committee to undertake a comprehensive assessment of the accounting profession (United States Treasury, 2008). The final report showed a continuing threat posed by Big Four dominance, and it recommended actions be taken to reduce the barriers that limit the growth of non-Big Four firms (United States Treasury, 2008, Sec. VIII: 4).

The second stream of literature on auditing-market consolidation studies the positive and negative effects that the mergers of accounting firms have, and have had, on competition, 
mainly relating to the Big Eight mergers of 1989. In regards to possible negative effects, Hermanson et al. (1990) were among the first academics to outline the antitrust considerations. The paper concluded that if the mergers were not opposed by the Justice Department or Federal Trade Commission, there would be significant effects on competition, clients and other Certified Public Accounting (CPA) firms. It also argued that the price competition was likely to decrease, and that some domestic clients may decide to switch from the largest firms to national, regional or local firms, resulting in a resurgence of these smaller firms (Hermanson et al., 1990, p. 15). Tonge and Wootton (1991) highlighted the positive effects of consolidation and found that the mergers would not necessarily result in less competition and higher prices. Still other studies have found little evidence to support the view that the 1989 mergers had any effect at all on competition (Menon and Williams, 2001; Iyer and Iyer, 1996).

Finally, the research on audit industry consolidation has paid attention to the study of the impact of the consolidation on the audit market share (Dunn et al., 2011, Hogan and Jeter, 1999, Danos and Eichenseher, Feldman, 2006). Particularly, Dunn et al. (2011) show that while overall market concentration increases, the market shares of the Big Four are more equal than were the market shares of the Big Five prior to the consolidation. However, the authors' findings also suggest that the largest four clients in each market they examined are more likely to share the same auditor after consolidation, which suggests that the largest clients face constrained choices. Similarly, the study of Hogan and Jeter (1999) provide evidence that the market leaders continue to increase their market shares, while Big six firms with smaller market shares lose market share over time.

While several above-mentioned academic and governmental reports uncovered the growth strategies and impacts of consolidation of the credit rating industry from different perspectives, most of the research on ESG rating agencies is focused on the measurement of companies' CSP, on exploring methodology and ranking criteria (Chatterji et al., 2009; Igalens and Gond, 2005; Wood and Jones, 1995). No attempt has been made to date to uncover growth strategies and consolidation determinants in the ESG rating industry. A notable exception is the Rate the Raters report, wherein the authors reinforced this blind spot by arguing that the financial non-viability of many ESG ratings, and the current inadequate demand and funding for the number of ESG ratings have contributed to the consolidation in 
the market (SustainAbility, 2010). The authors of the report point out the likelihood of a greater demand for fewer, higher-quality ESG ratings in the future, and predict that the market will settle on a few 'winners' in different ratings types. This lack of research might be due to the relatively recent appearance of the phenomenon, the lack of statistical data, and the nontransparence of ESG rating agencies regarding their growth strategies and motivations behind these strategies. This study seeks to overcome this gap by uncovering growth strategies of ESG rating agencies and providing evidence regarding the driving forces and impacts of consolidation in the ESG rating industry.

\section{METHODOLOGY AND DATASET}

\section{Research Method and Cases Selection}

Drawing on Eisenhardt (1989) and Yin (2003), we have undertaken a multi-case-study approach by focusing on four ESG rating agencies located in Europe and the United States to explain the consolidation of the industry; the evidence from multiple cases is considered more compelling, making the overall study more robust (Yin, 2003). Qualitative research is required when the purpose of the study is to increase understanding of a phenomenon about which little is known (Ghauri and Grønhaug, 2005), which is the situation of the present research. The focal phenomenon, namely growth strategies and the consolidation of the ESG rating field, have not been explored yet. Moreover, Lee (1999, p. 43) argues that qualitative research is appropriate when contextualization and vivid description under study is important. The four cases were chosen following theoretical sampling (Eisenhardt, 1989; Yin, 2003). All rating agencies had to have an international reach in regards to both clientele and the companies they rate. We selected two ESG rating agencies that have been particular active in industry consolidation: Morgan Stanley Capital International (MSCI), which has acquired two leading U.S. ESG rating agencies namely Innovest Strategic Value Advisors (hereafter referred to as Innovest) and KLD; and the French agency Vigeo, which has acquired Arèse, Stock at Stake and Avanzi SRI Research. These two examples were then compared with two ESG agencies that have not acquired other rating agencies: the Swiss-based Sustainable Asset Management (SAM) and the U.K.-based Ethical Investment Research Services Ltd (EIRIS). Over the past decade, these four rating agencies together have been the most active 
international players in the ESG rating sector. Table 1 outlines the key descriptors and growth strategies of studied ESG rating agencies.

\section{INSERT TABLE 1 ABOUT HERE}

\section{Data Collection and Analysis}

Interviews were chosen as our primary source of data, as they allowed us to elicit information that was complicated, sensitive and firm specific. Additionally, interviews enabled the interviewer to probe for further elaboration of answers and attitudes (Ghauri and Grønhaug, 2005).

In order to avoid 'company bias' answers and to correspond with the research's main interests, we adopted a multi-perspective approach by choosing two levels of interviewees to include 1) key individuals of ESG rating agencies and 2) experts and professionals of the ESG rating domain including Sustainable Development Managers and Corporate Affairs and Sustainability directors of companies rated by those agencies (see Appendix A). The rationale for the choice of informants was to have a broad range of interviewees in order to collect pluralist data describing competing versions of reality (Pettigrew, 1990).

During the semi-structured interviews, people referred to other ESG agencies and data providers; we mentioned this information in our analysis, but they are not the parts of our focal cases (e.g., BMJ Ratings, EthiFinance, Bloomberg, Thomson and Reuters). All interviews were taped and later transcribed and coded according to key issues of the research objectives. The quotations that appear in this study come from transcripts; however, certain details were removed to maintain confidentiality of information.

The evidence gathered from interviews - together with Rate the Raters report, Guides to Sustainability Analysis Organizations published by ORSE (2005, 2007, 2012), press releases and data provided in official websites of these ESG rating agencies - was triangulated in a conscious attempt at data-quality improvement.

In this research, we used the qualitative analysis software QSR ${ }^{\circledR}$ NVivo as a tool to assist with the coding process. The iterative work between first and secondary sources of information allowed us to develop appropriate themes and later reduce those themes to more precise categories (Miles and Huberman, 1994; Yin, 2003). Consequently, codes and sub- 
codes were created for driving forces and impacts with some later refinements as new important issues emerged (see Figure 1).

\section{INSERT FIGURE 1 ABOUT HERE}

\section{DATA DESCRIPTION}

This section provides data on the four rating agencies that we studied. It gives a brief historical review of each case and outlines their business models.

\section{Ethical Investment Research Services - EIRIS Foundation}

EIRIS is the oldest rating agency researched in this study. It was founded in 1983 as a not-forprofit organization in the United Kingdom and is a wholly owned subsidiary of the EIRIS foundation. It has kept this organizational status, which underlines its ambition to provide independent research and be somewhat removed from and reflective of the shareholder-valuemaximization goal of most investors.

EIRIS began its work with the goal of informing churches and charity organizations about the ethical dimensions of their investments, and the intention of helping them put their principles into practice when investing their pension funds and other assets. Over the years, EIRIS has expanded its client base and, among other things, it provides research for the FTSE4Good index. The EIRIS revenue model is geared toward investors, to whom it provides data on 300 indicators for over 3300 FTSE-listed companies worldwide, including emerging markets. EIRIS does not accept fees from companies that it rates (i.e., company-solicited ratings or ESG-related consulting services) and considers it as a conflict of interest.

As a registered charity, Eiris' profits are either reinvested in the subsidiary to further develop research capacity and expertise, or they are distributed to the charity so that it may continue its public information and grant-giving role. As apparent from the EIRIS Foundation Report and Account financial document and the Responsible Investment Platform, EIRIS turnover stalled in 2009 and 2010 (see Table 2), while profits fell. For this reason, EIRIS had to cut down its annual Gift Aid payment to the EIRIS Foundation. 


\section{INSERT TABLE 2 ABOUT HERE}

\section{Morgan Stanley Capital International - MSCI ESG Research Unit}

In contrast to the other three case companies, MSCI joined the rating agency sector quite late in the game. MSCI goes back to the Capital International Indices, which were first published in 1968. They were acquired in 1986 by Morgan Stanley and were rebranded as Morgan Stanley Capital International. In 2010, Morgan Stanley spun off MSCI in an Initial Public Offering (IPO). Over the past decade, MSCI has grown through a number of high-profile acquisitions of investment-risk metrics providers.

MSCI is a provider of decision support tools for over 2400 institutional investors, including some of the world's most influential mutual funds as well as a broad range of investment managers, pension funds and hedge funds. Today, MSCI is one of the leading providers of investment indices, competing with firms such as FTSE, Standard \& Poor's and Dow Jones. It is also competing with brokerage research organizations such as Bloomberg, which decided to enter this market by launching its own sustainability ratings. MSCI's index-related revenue is based on fees paid by investors who peg their funds to that index.

MSCI entered the ESG market by acquiring RiskMetrics, which enabled it to obtain the knowledge, capabilities, methods, and client bases of the two rating agencies that created and dominated the SRI sector since the 1990s. This is because RiskMetrics, in 2009, had consolidated the U.S. ESG-rating-agency sector by acquiring two industry pioneers: KLD and Innovest (see Figure 1). Based on the methodologies and client bases of these two firms, MSCI has been able to build a leading ESG rating presence.

Given that ESG ratings represent only a small part of MSCI's turnover, no separate data is available on turnover and profitability of this unit. However, a close reading of MSCI's Annual Report gives some indications as to the probable size of its ESG business. MSCI reports a rise of $\$ 13,200,000$ in turnover due to the acquisition of RiskMetrics. Given that KLD and Innovest were subcomponents of RiskMetrics, it can be assumed that neither KLD nor Innovest were much larger than Vigeo or EIRIS in 2010.

\section{Vigeo}


Vigeo was founded in 2002 as a limited company under French law. It followed a similar approach to MSCI by deciding to acquire France's ailing rating agency Arèse. In response to SAM forming a partnership with Dow Jones, Arèse launched Advanced Sustainable Performance Index (ASPI Eurozone) in partnership with STOXX. Vigeo draws on a diverse set of stakeholders that is meant to represent the different interests of a firm's stakeholders. It is a privately held company owned by financial managers and pension funds (47\%), trade unions (27\%), and some of the companies that it rates (26\%). In 2013, Vigeo launched an index family with the world's largest exchange group, New York Stock Exchange Euronext. In order to diversify revenues, Vigeo also offers company-solicited ratings (provided by Vigeo Entreprise) in addition to the investor-solicited ratings (provided by Vigeo Rating) that are the main source of Vigeo's revenues.

\section{INSERT TABLE 3 ABOUT HERE}

Despite the diversification of revenues, Vigeo has not always been able to produce profits (see Table 3). As stated in Vigeo's annual reports, the company has only had four positive years. For the majority of its existence, Vigeo has reported considerable losses. Turnoverwise, Vigeo is roughly the same size as EIRIS.

\section{Sustainable Asset Management (SAM)}

The last case of our study is SAM, created in 1995 by Reto Ringer, a Swiss investment banker. SAM's business model differs somewhat from those of traditional ESG rating agencies in that SAM is primarily carrying out research on its own behalf. It offers investment funds in areas such as clean energy, sustainability or water.

Provision of data to third parties came only as an afterthought, and was a response to demand from the marketplace. In 1999, SAM became the first ESG rating agency to join into a partnership with an existing index provider when it launched the DJSI.

The philosophy of SAM is its focus on sustainability and the future impact of companies' actions, rather than a focus on companies' past social responsibility. SAM looks on 
sustainability from business and investor perspectives, trying to see how sustainability adds value to companies.

\section{GROWTH STRATEGIES OF ESG RATING AGENCIES}

Most ESG rating agencies started out on the national level (e.g. Vigeo began its existence with a focus on the French market, EIRIS had its roots in the United Kingdom), catering for the local investors by rating firms in that region. However, soon ESG agencies began to reach out to other markets, both in terms of investors and in terms of firms being rated. Based on our data analysis, three types of growth strategies have emerged: organic growth, partnerships, mergers and acquisitions. These three strategies are briefly analyzed in this section.

\section{Organic growth and Partnerships}

In a globalized world, SRI investors expect data on firms from all major countries. As a result, several agencies have begun opening their own outposts to access data and to attract more clients. Innovest, for example, had offices in London and Paris, EIRIS has offices in Boston and Paris, and France-based Vigeo has an office in London. The advantage of this organic growth lies in the fact that ESG ratings can better control the applications of their research methods. Moreover, this growth also helps to build a global brand in the ESG industry.

A cheaper alternative to organic growth is the establishment of exclusive partnerships, an approach that was particularly used in the early days of the ESG industry. It was by way of this method that the Sustainable Investment Research International (SiRi) Group was founded in 2001 under the leadership of KLD. The SiRi alliance included, among others, ESG agencies such as Arèse in France and Avanzi SRI Research in Italy. However, when Arèse and Avanzi SRI Research were acquired by Vigeo, KLD lost these partners, thus highlighting one of the main disadvantages of the partnership system.

EIRIS has also used partnerships as a main growth element. In order to provide a truly global research, EIRIS draws on a network of seven international research partners in the EIRIS global platform who have strong expertise and provide insight about the local area. One of the reasons that EIRIS has been slow to embrace organic growth may lie in its organizational 
structure. It is owned by a charitable foundation; consequently, it doesn't have the amount of resources to invest that would be available to a for-profit owned company. EIRIS thus has to rely on its local partners to provide data.

"We prefer to have a Global network of alliances and partnerships rather than spending money buying other research groups. Most of our research partners are also sales partners, so we are selling across Australia, Germany, Spain, Mexico, Korea and Israel. We also have set up offices in Boston and in Paris. We choose not to outsource research to offshore research houses, as it is important to have tight control of research quality. At the same time, we seek new local partners where we can gain new expertise. [...] Our key USPs are being both foundation-owned and independent with a network of partners, and going from being a UK-centric organization into a global organization whilst maintaining our independence”. (EIRIS interview)

\section{Mergers and acquisitions}

Regional Extension. As reported by the majority of interviewees, without networking and economies of scale, it is very difficult to generate revenues in this industry. ESG rating agencies were on the edge, struggling to remain profitable and to offer good quality research. Some of them were forced to sell out their companies for the sake of their reputations and the jobs of their employees. The first type of consolidation observed was regional extension, which occurs when two or more ESG rating agencies decide to merge and join their forces.

"You have to be in all of these different markets. You can't just be only a rating agency for France. So, in all of these countries you need a consolidation”. (TBLI Group, interview)

Vigeo launched the first round of cross-border consolidation in the ESG industry in order to increase its geographical coverage, clients and establish a stronger presence in the European ESG market, thus a better position as compared to its main French competitors, BMJ Ratings and EthiFinance. At the end of 2005, Vigeo acquired the Belgian company Stock at Stake and became the owner of Ethibel Sustainability Indices (ESI). The following year, Vigeo bought the Italian company Avanzi SRI Research (see Figure 2). Both Stock at Stake and Avanzi SRI Research were part of the EIRIS/KLD research network prior to being bought, thus Vigeo had some knowledge about their methodologies and client bases. 
"Investors wanted a broader geographical coverage. In the beginning, Vigeo was purely a French company, whereas now it can offer a wider range of services and analyses in Maghreb, Italy and Belgium”. (French Network on CSR Study, interview)

The growth strategy of Vigeo followed a pattern that can be framed to some extent within the literature on the internationalization of service industries, which prefer entering new markets through acquisitions often with a local partner (Sarathy, 1994).

Entry of financial data providers and asset managers into the ESG rating industry. On the one hand, the market has seen consolidation between purely ESG rating agencies; on the other hand, some large data providers and asset managers-such as MSCI, Bloomberg, and Robeco-have shown an expanding interest in entering the ESG rating field. They have created economies of scope by offering both specific views on ESG performance and fullservice research to their clients, either by way of acquiring or merging with ESG rating agencies, or by developing in-house CSR evaluation products (e.g. Bloomberg). This has certainly affected the competition and the pricing, as the sell-side broker can deliver the fullservice research to clients with attractive prices.

As such, MSCI invested heavily in ESG research by acquiring, in 2010, KLD and Innovest, which were already parts of RiskMetrics Group. Robeco bought SAM in 2006. With the jump of these big players into the market, ESG ratings are now solidly in the mainstream, as these companies have resources and very high credibility within the mainstream investment community.

"The fact that MSCI is now offering ESG indexes is attacking us, because we have another strong competitor in the market. At the beginning, the main competitor was FTSE4Good ...[...]... and now MSCI with its ESG indexes has become a big competitor. Again, every time you have a competitor, it's on the one hand bad and on the other hand it's good, because it shows that the market is getting bigger." (SAM, interview)

For example, Robeco is now using the information provided by SAM for its responsibleinvestment products. Thus, SAM's products and services have a wider application, and it is easier to make the business case for doing their research.

"Well, we consider ourselves asset managers. We were looking for a partner ...[...]... so at that time ...[...]... the issue for SAM was how to grow more and how to become also more financially stable. In this perspective, different options have been seen, and the Robeco option was chosen because it allowed SAM to be kept as a company, not to 
be slashed into different parts, with the perspective for SAM to be able to tap into a larger market and so on. It was mainly done considering the benefit for asset management side." (SAM, interview)

\section{DRIVING FORCES AND IMPACTS OF COSOLIDATION}

Our findings also revealed the main drivers of consolidation and the impacts of consolidation on the ESG rating industry. The consolidation trend of the ESG rating market can be best viewed as a result of a combination of two underlying motives: financial (economies of scale, financial sustainability) and market power (integration and collaboration with acquiring firm, standardization, building a global-market-leader reputation). These consolidations have carried both positive and negative aspects such as quality loss and price war, motivation decrease, and knowledge loss. Below we discuss each motivation and impact and, where possible, compare our results with previous literature on the consolidation of accounting and management consulting firms.

\section{Financial motivations}

Economies of scale. Our findings show, that it has become mainstream for ESG rating agencies to be more stable, to deliver more sophisticated products and services on more numerous locations in the world. Economies of scale are needed to reach that level.

Scaling up with MSCI and possessing infrastructure and place allowed both KLD and Innovest to perform activities that they couldn't have done previously, being smaller separate industries. The Executive Director and Head of Product Development of ESG research at MSCI reflected that upon the time when he was still in INNOVEST (of which he was a president and co-founder), the company was intending to do the activities, which they are currently doing in MSCI. As such, MSCI financed the partnership with Barkley's Capital to do ESG bond indexes and allowed mapping all the corporate ratings they do to corporate bonds. Moreover, scaling up with MSCI created possibilities for rating all the sovereigns INNOVEST needed for sovereign bonds.

From MSCI perspective, consolidation with RiskMetrics was a cheap way to get into the market of ESG ratings. By acquiring RiskMetrics, MSCI acquired many years of experience and knowledge, as well as the reputation of KLD and Innovest in one go. Building this up without consolidation would have been quite costly to MSCI. 
Overall, through large-scale audit assignments, ESG rating agencies are able to achieve higher margins, take advantage of economies of scale and develop global brand and reputation.

Financial sustainability. A number of ESG rating agencies have a difficult time raising money and growing independently without economies of scale and networking effects. Because of increasing demands from buy-side players, as well as the rise of new ESG issues to be measured and the need for extending regional reach, the overall demands run faster than the revenue streams do.

Having begun as a privately held company, SAM eventually realized that it was not able to reach profitability on its own. Therefore, in 2006, its shareholders sold a part of SAM's shares to Robeco (see Figure 2), a prominent Dutch asset management company that is a full subsidiary of Rabobank. Robeco fully acquired SAM in 2010 and renamed the firm RobecoSAM in 2013. For the sake of brevity, we kept the established brand name of SAM in this paper.

"I ran a company Innovest, and we built up a very good brand and we had great clients, but it was pretty hard. We had all sorts of constraints. It's not that it's not hard now. Doing business is hard, but we are way more stable in terms of data delivery and so on, which makes us a more compelling offer to institutions. I know from the inside and I know from the other small firms out there. They are hard to run and there is not a lot of money in this field either. Another thing is that the part of the consolidation was absolutely necessary because when you added up everybody in the ESG field-all their incomes and all their expenses-nobody was making any money. It's because most of the people by their natures are interested in subject matter, and they are actually more $N G O$ and inspirational [CSR motivated] than they are saying that this is a fantastic [successful] business.” (MSCI, interview)

In sum, ESG rating agencies have to build up a huge scale in order to have a commercial business model and may have to provide both company-solicited and investor-solicited services. Meanwhile, maintaining independence for a rating agency is essential in protecting its credibility and ensuring that the objectivity of its judgment is not impaired by any conflicts of interests, which is also a longstanding question of criticism for auditing and management consulting firms.

The issue of whether the provision of company-solicited and investor-solicited services weakens ESG rating agencies' independence concerns all the rating agencies of our study, except Eiris. In the case of auditing firms, Ernst and Young was the first to overcame this problem, in 2000 , by formally and fully separating its consulting practices via a sale to the French IT services company Cap Gemini (and creating a new company Cap Gemini Ernst \& 
Young) following the concerns raised by the U.S. Securities and Exchange Commission (SEC) about potential conflicts of interest between the consulting and auditing activities provided by the Big 5. The same year KPMG divested its consultancy group renamed as KPMG Consulting. Before that Arthur Andersen separated into two global business units Arthur Andersen and Andersen Consulting. If the interest of legislators and regulators about the impact of auditors' fees on audit judgments (SEC 2000, U.S. House of Representatives 2002) and particularly Sarbanes-Oxley act limited the type of non-audit services an American accounting firm is allowed to offer to an audit client, to date the ESG rating field remains non regulated on this issue and leaves the boundaries of the conflict of interest to be managed by the agencies themselves. In the case of Vigeo, even though company-solicited notation is not the main source of revenue, its dependence on the client increases and investor-solicited notation may be compromised by the risk of losing those consulting projects (included in company-solicited notation) as a source of revenue to remain profitable.

\section{Market Power}

Integration and collaboration with acquiring firm. Some interviewees found synergies with acquiring firms to be drivers for consolidation. The transition period of consolidation might be long, as the gains from market consolidation only fully emerge after some time has passed. Therefore, the newly consolidated ESG rating agency requires some time to 1) be integrated into the business of the acquiring company, 2) retrain personnel with different institutional backgrounds and approaches to ESG assessment, and 3) adapt to the change in company culture and values.

However, if the acquiring ESG rating agency has the ability to correctly use the power of the acquired firm and combine it with its own network advantages in the market, both companies can benefit from the learning, which may result in a creation of a more effective approach. This, in turn, can augment the quality and the range of the available services by making them more consistent.

As such, there was a very good overlap between the legacy of Innovest and KLD products, although Innovest was much more focused on the impact to a company (e.g., how ESG factors could affect long-term shareholder value), whereas KLD was more focused on the impact to external stakeholders (e.g., how that company's operations could impact society and have a more global impact). MSCI was able to partially integrate both. What Innovest brought 
to the table was that they were strong on risk, an aspect that KLD didn't focus on. KLD contributed a much stronger database of management indicators - which was something that Innovest was lacking. MSCI adapted the Innovest model for ratings, using a combination of KLD management indicators and Innovest risk indicators, both of which were relevant by industry.

"When RiskMetrics bought Innovest, they didn't have any ESG research. We were basically this new unit and the integration was not really an issue. When KLD came, they had their own products. They also had indexes, which Innovest didn't have. We combined the different products, reworked ...[...]... and now we have those two products. [...] We went a long way to improve the products, changing the way that they can exist together and respond to different demands. I think MSCI has brought a lot of technology and IT expertise in terms of platforms that we have been using. Everything is much more formalized than it used to be, because we were a small firm and didn't have the ability to do that. Now I think that's something really positive." (MSCI, interview)

Setting a standard and building a global-market-leader reputation. Consolidation allows an ESG rating agency to become the standard in the industry by eliminating competing methodologies, mutualizing similar methodologies, or making the agency's own methodology more predominant. This standardization can in turn influence and contribute to the institutionalization of the CSR field.

Meanwhile, ESG ratings exist more in a service industry where reputation matters a great deal. For an ESG rating agency, the reputation is created by the ability to impact local and global markets, but also by the number of (global) customers.

"If one of your customers is Veolia in France, potentially it's Veolia worldwide. If you target IBM in France, potentially, if you are credible, you target IBM worldwide. And if you have IBM and Veolia as customers, probably the local company will accept your offer rather than [that of] your competitor's and will pay a higher price for you than for the local competitor." (BMJ Ratings, interview)

\section{Quality loss and price war}

As reported by our interviewees, there have been a lot of implications that are not necessarily positive regarding the quality of the research provided by ESG rating agencies that were merged or acquired by other entities. If the acquiring company streamlines the methodology in order to reduce costs and make the methodology smaller, more superficial 
and less cost intensive, then it is likely that the agency could lose out on quality aspects. The concentration of supply in ESG rating markets is harmful for the quality of the research, because the lack of competition reduces the incentives of existing agencies to conduct highquality audits and may increase the potential for collusive behavior. This holds similarities with the issue raised in the preface of the report from the GAO (2003) on the consolidation of accounting and management consulting firms and its potential choice, price, quality, and concentration risk concerns.

"[...] My worry is that the quality and the choice for clients will go down. [...] The market will be less flexible and everything will just have to fit into the big box that the large players want the clients to fit into, which is not the approach that we do. Maybe that's fine, but then I do worry that if the quality of traditional rating agencies goes down, then the clients, all the financial community, will turn to people like Bloomberg, who have terminals and who are trying to double their business now. Maybe their quality is not that conceived. They haven't got the long-standing feel for the importance of ESG.” (EIRIS, interview)

\section{Knowledge loss and motivation decrease}

Another negative aspect of consolidation is that most of the companies' former pioneers, knowledge leaders and independent thinkers have left the companies, as they perceived a diminution of motivation and not belonging to the company.

The majority of those who departed have founded their own companies, started providing consulting services to major corporations, or joined smaller companies where they can bring in their expertise and knowledge again. Given that ESG rating is a highly knowledge-based industry, this can have a direct impact on the quality of the research, as the methodology is only as good as the quality of the employees.

"I was one of the first to leave the company. [...] I stayed at RiskMetrics for a while but then I left. [...] I was already working for a buy-side hedge fund in clean tech, and I just moved to them very quietly. A little later, I saw everybody leaving. [...] We had a very difficult time once we got to RiskMetrics figuring out who we were going to sell to, who was going to buy this rating." (Innovest, interview)

Meanwhile, an ESG rating agency might undermine the trust of the loyal clients; the advanced investors (in the way they use sustainability data or rating information) realize that if a company becomes a member of a large organization, investors won't get the quality of research that they need. For example, Institutional Shareholder Service, which rated MSCI as 
one of the lowest on governance criteria, was bought by MSCI. This has disappointed many investors of the field.

"The vulnerability is [that there is] some lost of specialization. This usually means that you end up dealing with maybe higher data that you didn't specialize in. would imagine it's similar to S\&P, Moody's, and Fitch kind of issue, where errors in the model are amplified because everyone is using a similar model. (MSCI, interview)

\section{CONCLUSION}

In this paper, we have taken the first step toward the study of growth strategies and consolidation of ESG rating agencies. Based on our findings, we categorized growth strategies into regional extension or cross-border acquisitions (e.g., Vigeo with Stock at Stake and Avanzi SRI Research); and entry of big data providers, asset management companies, and banks into the ESG rating industry through merger or acquisitions (e.g., MSCI with RiskMetrics and Robeco with SAM). In the case of Vigeo and MSCI, our findings converge with Kipping and Clark's (2012) arguments explaining mergers of accounting and management consulting firms. The large scale and presence in big cities would enable these rating agencies to cut costs, to offer sophisticated clients more services and to reshape their position as one of the industry leaders. Within this part we also presented organic growth and partnerships as growth strategies (e.g. EIRIS).

Above-mentioned findings allow us concluding that this industry does not purely follow a standard industry life cycle, because the permeable boundaries of the industry have resulted in mergers between purely ESG players but also between ESG rating agencies and broader data providers or brokerage organizations. This has highly fragmented the industry and made difficult the entry to the market, because now big entities such as MSCI are becoming dominant in the field and it is increasingly challenging for new entrants to replicate the ratings at lower cost than do the existing players. On the one hand, this raises a question of the deinstitutionalization of ESG rating field and possible 'death' of Institutional Entrepreneurs (pure ESG rating agencies). On the other hand, the entry of various above mentioned organizations into ESG rating industry provides strong evidence that data providers and brokerage research organizations strongly view ESG ratings as profitable activities.

Our findings highlighted motivations but also impacts of the current consolidation trend, which have carried both positive and negative aspects for players from each side of the 
industry. Depending on the level of investors' professionalism, the consolidation may be seen as a positive or negative trend. Highly knowledgeable investors, in terms of the ways in which they use the data, may realize that the quality of the data will not be the same if the ESG rating agency has been acquired by a big data provider. Less sophisticated investors are less aware of potential quality deterioration.

Meanwhile, clients benefit from consolidation if the rating agency is embedded in a more stable financial entity that guarantees long-term survival. Also, from the ESG market's perspective, consolidation leads to the provision of increasingly standardized and commoditized sustainability data. However, several of our respondents indicated that consolidation has caused an erosion of trust among investors, when doubts remained about whether values remain the same when ESG agencies are embedded in a larger organization. Interview data suggests that employees of acquired firms tended to lose motivation. This was partly explained by feedback stating that the staff felt they no longer belonged to the group or could contribute to its development in the same way they did before.

Consolidation was also seen skeptically by some investors who prefer to see a competitive landscape where they don't have to rely on a few mega players, as in the credit ranking industry. This would indicate a demand for a variety of independent market players who are jointly presumed to guarantee overall quality.

On the positive side, consolidation has increased the market share of the remaining rating agencies, which consolidated by acquiring businesses and their clients. Having additional companies on their client lists has added value and reputation to the ESG rating agencies. Furthermore, the field has become more professionalized, and remaining players seem to be financially more robust.

\section{Future waves of consolidation}

Although the main wave of consolidation has slow down considerably, in our opinion there could be a potential for further ESG rating market consolidation, where the quality and value of the data will be the main drivers of success. Joining established ESG rating agencies, asset management companies, brokerage research organizations and even financial rating agencies might be the only way local small ESG rating agencies can compete by offering a broad array of products and services to clients.

However, there is always going to be a thriving industry of innovative ESG rating 
agencies that are specialized with their market focus either by the geography or by the issues they cover, as sometimes there is a cultural preference for local firms on the part of businesses. That level of the market will continue to be vital because of increasing interest in ESG investing. Besides, there will be growing numbers in Asia, where there are not really many incumbents for the moment. If in the long-term success of management-consulting companies depends on the establishment of successful external (client) and internal (partner) networks (Kipping, 1999), the rating agencies, which will thrive in the future, may be those that will generate the most valuable information for investors, companies and other users.

\section{Limitations and Future Research}

In this paper, we examined growth strategies and consolidation of ESG rating agencies based on selected representative cases and we accept that there might be more drivers and impacts of consolidation. We do not submit that our cases show all the particularities of ESG-ratingindustry consolidation, but we believe that our set collectively covers the main tendency and gives insight into understanding the phenomenon of consolidation, its drivers and its impacts. Yet, we are mindful of how much more effort is necessary in order to fully explain the consolidation trend of the ESG rating industry.

While our sample covers the United States and some European countries, additional research illuminating the patterns of ESG-rating-industry consolidation will help to explore the similarities and differences in other countries by enabling a more complete assessment of our contribution. We also encourage other researchers to conduct studies of changes in the business models of individual ESG rating agencies before, during and after consolidation, and to question which business models will be the most sustainable in the long term. Finally, there is a need to explore how rating agencies transferred their methodologies into other markets and the extent to which it influenced the way ESG audits are carried out in those markets.

\section{REFERENCES}

Arjaliès D.-L. 2010. A social movement perspective on finance: how socially responsible investment mattered. Journal of Business Ethics 92(1): 57-78.

Avetisyan E, Ferrary M. 2013. Dynamics of stakeholders' implications in the institutionalization of CSR Field in France and in the United States. Journal of Business Ethics 115(1): 115-133. 
Berman S. L, Wicks A.C, Kotha S, Jones, T.M. 1999. Does stakeholder orientation matter? The relationship between stakeholder management models and firm financial performance. Academy of Management Journal 42, 488-506.

Brown B, Perry S. 1994. Removing the financial performance halo from Fortune's "Most Admired" companies. Academy of Management Journal 37(5): 1347-1359.

Chatterji A.K, Toffel M.W. 2010. How firms respond to being rated? Strategic Management Journal 31(9): 917-945.

Chatterji A.K, Levine D.I, Toffel M.W. 2009. How well do social ratings actually measure corporate social responsibility?. Journal of Economics \& Management Strategy 18(1): 125169.

Collison D, Cobb G, Power D, Stevenson L. 2009. FTSE4Good: Exploring its implications for corporate conduct. Accounting, Auditing \& Accountability Journal 22(1): 35-58.

Danos P, Eichenseher J.W. 1982. Audit industry dynamics: factors affecting changes in clientindustry market shares. Journal of Accounting Research 20(2), 604-616.

Delmas M, Blass V.D. 2010. Measuring corporate environmental performance: the trade-offs of sustainability ratings. Business Strategy and the Environment 19(4): 245-260.

Dillman, D. A. 2000. Mail and internet surveys: the tailored design method (Vol. 2). New York: Willey.

Dunn K, Kohlbeck M, Mayhew B.W. 2011. The impact of the Big 4 consolidation on audit market share equality. Auditing: A Journal of Practice \& Theory 30(1): 49-73.

Eichenseher J.W, Danos P. 1981. The analysis of industry-specific auditor concentration: towards an explanatory model. Accounting Review 56: 479-492.

Eisenhardt K. 1989. Building theories from case study research. Academy of Management Review 14(4): 532-550.

Entine J. 2003a. The myth of social investing. Organization \& Environment 16(3) : 352-368.

Entine J. 2003b. Capitalism's Trojan Horse: how the "Social Investment" movement undermines stakeholder relations and emboldens the anti-free market activities of NGOs, American Enterprise Institute Policy Papers.

European Commission. 2010. Green paper: audit policy: lessons from the crisis.

Feldman E. 2006. A basic quantification of completive implication of the demise of Arthur Andersen, Review of Industrial Organization 29: 193-212.

Fieseler C. 2011. On the corporate social responsibility perceptions of equity analysts. Business Ethics: A European Review 20(2): 131-147.

Francis J.R, Michas P.N, Seavey S.E. 2013. Does audit market concentration harm the quality of audited earnings? Evidence from audit markets in 42 countries. Contemporary Accounting Research 30(1): 325-355.

Galbreath J. 2013. ESG in focus: the Australian evidence. Journal of Business Ethics 1-13.

Garnsey E.1998. A theory of the early growth of the firm. Industrial and Corporate Change 7 (3): 523-556.

General Accounting Office. 2003. Public accounting firms: mandated study on consolidation and competition.

Ghauri P, Grønhaug K. 2005. Research methods in business studies (3rd eds). Prentice Hall: London.

Government Accountability Office. 2008. Audits of public companies: continued concentration in audit market for large public companies does not call for immediate action.

Graves S.B, Waddock S.A. 1994. Institutional owners and corporate social performance. Academy of Management Journal 37(4): 1034-1046. 
Harrison J.S, Freeman R.E. 1999. Stakeholders, social responsibility, and performance: empirical evidence and theoretical perspectives. Academy of Management Journal 42(5): 479-485.

Hart S.L, Milstein M.B. 2003. Creating sustainable value. The Academy of Management Executive 17(2), 56-67.

Hermanson R, Plunkett L, Turner D. 1990. Mergers among the big eight accounting firms: Some antitrust policy considerations. Corporate Growth Report 8(3): 12-15.

Hill R.P, Ainscough T, Shank T, Manullang D. 2007. Corporate social responsibility and socially responsible investing: a global perspective. Journal of Business Ethics 70(2), 165-174.

Hinings C.R, Greenwood R, Cooper D. 1999. The dynamics of change in large accounting firms. Restructuring the professional organization, 131-153.

Hockerts K, Moir L. 2004. Communicating corporate responsibility to investors: The changing role of the investor relations function. Journal of Business Ethics 52(1): 85-98.

Hogan C, Jeter D.C. 1999. Industry specialization by auditors. A Journal of Practice \& Theory 18: $1-17$.

House of Lords. 2010. Call for evidence: Auditors: market concentration and their role. Select Committee on Economic Affairs.

Hutton R.B, D'Antonio L. et al. 1998. Socially responsible investing. Business \& Society 37: 281305.

Igalens J, Gond J.P. 2005. Measuring corporate social performance in France: a critical and empirical analysis of ARESE data. Journal of Business Ethics 56(2): 131-148.

Iyer V.M, Iyer G.S. 1996. Effect of Big 8 mergers on audit fees: evidence from the United Kingdom. Auditing: A Journal of Practice \& Theory 15(2), 123-132.

Johnson R.A, Greening D.W. 1999. The effects of corporate governance and institutional ownership types on corporate social performance. The Academy of Management Journal 42(5): 564-576.

Johnsen D.B. 2003. Socially responsible investing: a critical appraisal. Journal of Business Ethics 43(3): 219-222.

Jones E. 1995. True and fair: A history of Price Waterhouse. London: Hamish Hamilton.

Kipping M. 1999. American management consulting companies in Western Europe, 1920 to 1990: products, reputation, and relationships. Business History Review 73(02): 190-220.

Kipping M, Clark T. 2012. Researching management consulting: an introduction to the handbook. In The Oxford handbook of management consultancy, Oxford : Oxford University Press

Koellner T, Weber O, Fenchel M, Scholz R. 2005. Principles for sustainability rating of investment funds. Business Strategy and the Environment 14(1): 54-70.

Lee T.W. 1999. Using qualitative methods in organizational research. Thousand Oaks, CA: Sage.

McDougald M.S, Greenwood R. 2012. Cuckoo in the nest? The rise of management consulting in large accounting firms. In The Oxford handbook of management consulting, Oxford : Oxford University Press

Menon K, Williams D.D. 2001. Long-term trends in audit fees. Auditing: A Journal of Practice \& Theory 20(1): 115-136.

Miles M.B, Huberman A.M. 1994. Qualitative data analysis: an expanded sourcebook (2nd eds). Thousand Oaks, CA: Sage.

Morsing M, Schultz M. 2006. Corporate social responsibility communication: stakeholder information, response and involvement strategies. Business Ethics: A European Review 15(4): 323-338.

ORSE. 2012. Guide des Organismes d'Analyse Sociale et Environnementale.

ORSE. 2007. Guide des Organismes d'Analyse Sociale et Environnementale.

ORSE. 2005. Guide to Sustainability Analysis Organizations. Paris: ADEME/ORSE. 
Oxera. 2006. Competition and choice in the U.K. audit market: Prepared for the Department of Trade and Industry and Financial Reporting Council. Oxera Consulting (Oxford, England).

Oxera. 2007. Ownership rules of audit firms and their consequences for audit market concentration. Oxera Consulting (Oxford, England).

Pettigrew A. M. 1990. Longitudinal field research on change: theory and practice. Organization science 1(3): 267-292.

Porter M. E. 1980. Competitive strategy. New York: Free Press. Richardson

Ruf B.M, Muralidhar K, Paul K. 1998. The development of a systematic, aggregate measure of corporate social performance. Journal of Management 24(1): 119-133.

Sarathy R. 1994. Global Strategy in Service Industries. Long Range Planning 27: 115-124.

Sarbanes-Oxley Act. 2002. Public Law No. 107-204. Washington, D.C.: Government Printing Office.

Securities and Exchange Commission. 2000. Final Rule: Revision of the Commission's Auditor Independence Requirements. Washington, D.C.: Government Printing Office

Scalet S, Kelly T. F. 2010. CSR rating agencies: what is their global impact?. Journal of Business Ethics 94(1), 69-88.

Schueth S.2003. Socially responsible investing in the United States. Journal of Business Ethics, 43(3): 189-194.

Schrader U. 2006. Ignorant advice-customer advisory service for ethical investment funds. Business Strategy and the Environment 15(3): 200-214.

Shane S.A. 1996. Hybrid organizational arrangements and their implications for firm growth and survival: a study of new franchisors. Academy of Management Journal 39: 216-234.

Slager R, Gond J.-P, Moon J. 2012. Standardization as institutional work: the regulatory power of a responsible investment standard. Organization Studies 33(5-6): 763-790.

SustainAbility. 2010. Rate the Raters. Phase 2, Inventory of the Ratings Universe. London.

Thomas A.S, Simerly R.L. 1995. Internal determinants of corporate social performance: the role of top managers. Academy of Management Proceedings 1: 411-415. Academy of Management.

Tonge S.D, Wootton C.W. 1991. Auditor concentration and competition among the large public accounting firms: post-merger status and future implications. Journal of Accounting and Public Policy 10(2), 157-172.

Turban D.B, Greening D.W. 1997. Corporate social performance and organizational attractiveness to prospective employees. Academy of Management Journal 40(3): 658-672.

U.S House of Representatives. (2002). Hearings before the committee on financial services: (March 13). Washington, D.C.: Government Printing Office.

United States Treasury. 2006. Remarks by Treasury Secretary Henry M. Paulson on the competitiveness of U.S. capital markets - Economic Club of New York. New York, NY

United States Treasury. 2008. Advisory committee on the auditing profession: Final report.

Vallentin S. 2003. Socially responsible investing - Approaches and perspectives. In M. Morsing \& C.Thyssen (eds.), Corporate values and responsibility - The case of Denmark (pp.257267). Denmark: Gylling.

Vandekerckhove W, Leys J, Van Braeckel D. 2008. A speech-act model for talking to management. Building a framework for evaluating communication within the SRI engagement process. Journal of Business Ethics 82(1): 77-91.

Waddock S. 2003. Myths and realities of social investing. Organization \& environment 16(3): 369-380.

Waddock S.A, Graves S.B. 1997. The corporate social performance-financial performance link. Strategic Management Journal 18: 303-319. 
Wood D.J, Jones E.J. 1995. Stakeholder mismatching: a theoretical problem in empirical research on corporate social performance. The International Journal of Organizational Analysis 3(3): 229-267.

Yin R. 2003. Case study research (3rd eds). Thousand Oaks, CA: Sage. 
Table 1. Key Descriptors of studied ESG Rating Agencies

\begin{tabular}{|c|c|c|c|c|}
\hline & EIRIS & SAM & $\begin{array}{c}\text { MSCI } \\
\text { ESG Research } \\
\text { Business Unit }\end{array}$ & Vigeo \\
\hline Founded & 1983 & 1995 & 1969 & 2002 \\
\hline $\begin{array}{l}\text { Acquisitions of other } \\
\text { ESG rating agencies }\end{array}$ & & & $\begin{array}{l}\text { MSCI acquired } \\
\text { RiskMetrics in } \\
\text { 2010. RiskMetrics } \\
\text { acquired KLD and } \\
\text { Innovest in } 2009 \\
\end{array}$ & $\begin{array}{c}\text { Vigeo acquired Arèse } \\
\text { (France) in 2002, Stock at } \\
\text { Stake (Belgium) in } 2005 \text { and } \\
\text { Avanzi SRI Research (Italy) } \\
\text { in } 2007\end{array}$ \\
\hline Ownership Structure & $\begin{array}{l}\text { EIRIS Ltd is a } \\
\text { wholly owned } \\
\text { subsidiary of EIRIS } \\
\text { foundation, which is } \\
\text { a registered charity }\end{array}$ & $\begin{array}{c}\text { Robeco } \\
\text { acquired 64\% of } \\
\text { SAM in 2007; SAM } \\
\text { is now wholly } \\
\text { owned by Robeco }\end{array}$ & $\begin{array}{l}\text { Publicly traded since } \\
\text { 1986. The majority } \\
\text { shareholder is } \\
\text { Morgan Stanley }\end{array}$ & $\begin{array}{c}\text { Vigeo is a privately held } \\
\text { company owned by financial } \\
\text { managers and pension funds } \\
(47 \%) \text {, trade unions }(27 \%), \\
\text { companies }(26 \%)\end{array}$ \\
\hline $\begin{array}{l}\text { Provide research for } \\
\text { the following index }\end{array}$ & $\begin{array}{c}\text { FTSE4Good } \\
\text { Indexes } \\
\text { ICP Sustentable }\end{array}$ & DJSI & $\begin{array}{c}\text { MSCI Socially } \\
\text { Responsible Indexes }\end{array}$ & $\begin{array}{c}\text { ASPI; ESI } \\
\text { NYSE Euronext Indexes }\end{array}$ \\
\hline $\begin{array}{c}\text { Number of } \\
\text { employees in } 2012\end{array}$ & $\begin{array}{c}\sim 60 \text { (out of which, } \\
36 \text { full-time analysts } \\
\text { plus } 25 \text { via partners) }\end{array}$ & $\sim 130$ employees & $\begin{array}{c}130 \text { (out of which, } \\
80 \text { full-time } \\
\text { analysts) } \\
\end{array}$ & $\begin{array}{c}\sim 105 \text { (out of which, } 60 \text { full- } \\
\text { time analysts and } 21 \text { full- } \\
\text { time auditors) }\end{array}$ \\
\hline Growth Strategies & $\begin{array}{l}\text { Organic Growth and } \\
\text { Partnerships }\end{array}$ & $\begin{array}{l}\text { Merger and } \\
\text { Acquisition }\end{array}$ & Acquisition & Acquisition \\
\hline
\end{tabular}

Sources: Data in this table has been collected in the Guide to Sustainability Analyses Organizations, produced by the ORSE (2012, 2007) and official websites of ESG rating agencies.

Table 2. EIRIS's financial results (£)

\begin{tabular}{lrrrrr}
\hline & $\mathbf{2 0 0 6}$ & $\mathbf{2 0 0 7}$ & $\mathbf{2 0 0 8}$ & $\mathbf{2 0 0 9}$ & $\mathbf{2 0 1 0}$ \\
\hline Turnover & 2123186 & 2585220 & 3258189 & 3233084 & 3271962 \\
\hline $\begin{array}{l}\text { Profit/(loss) before Gift Aid } \\
\text { Gif Aid to EIRIS Foundation }\end{array}$ & 8653 & 207025 & 246391 & 77868 & 8515 \\
\hline $\begin{array}{l}\text { Profit/loss on ordinary activities } \\
\text { before taxation }\end{array}$ & & -82825 & -173196 & -55559 & -28859 \\
\hline $\begin{array}{l}\text { Corporation tax payable } \\
\text { Retained Profit / (loss) for the }\end{array}$ & & 124200 & 73195 & 22309 & -20344 \\
year & 8653 & -675 & -13343 & -2198 \\
\hline
\end{tabular}

Table 3. Vigeo's financial results $(€)$

\begin{tabular}{|c|c|c|c|c|c|c|c|c|c|c|}
\hline Vigeo & 2003 & 2004 & $2005^{*}$ & 2006 *** & 2007 & 2008 & 2009 & 2010 & 2011 & 2012 \\
\hline Turnover & 1129356 & 2709911 & 3297276 & 4300927 & 6475000 & 6886000 & 6708000 & 7976000 & 8071000 & 8143000 \\
\hline Vigeo Rating & 834148 & 1624914 & 2052353 & & & & 4437000 & 5002000 & 5279000 & 5621000 \\
\hline Vigeo Entreprise & 295208 & 1084997 & 1244923 & & & & 1901000 & 2296000 & 2246000 & 2013000 \\
\hline
\end{tabular}

* Stock at Stake not included; ** only Vigeo 